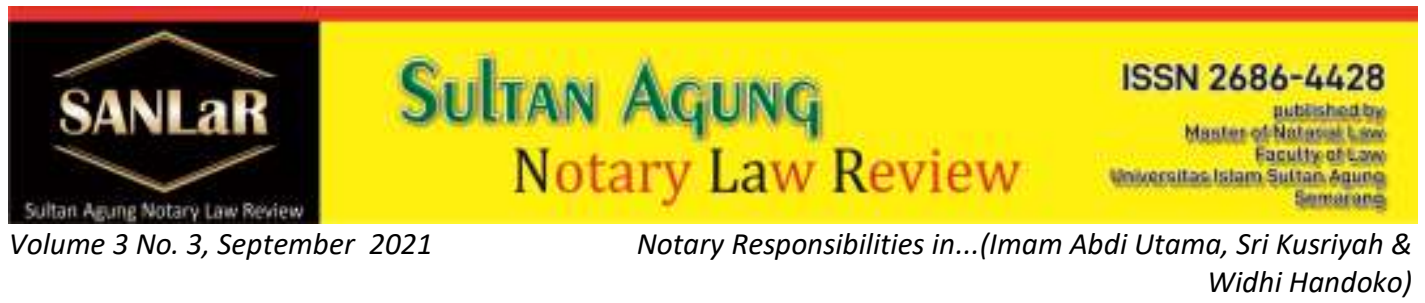

\title{
Notary Responsibilities in Making Authentic Deeds for Interest of Community from Progressive Law Perspective
}

\author{
Imam Abdi Utama*', Sri Kusriyah ${ }^{* *}$ and Widhi Handoko**) \\ $\left.{ }^{*}\right)$ Faculty of Law, Universitas Islam Sultan Agung (UNISSULA) Semarang, E-mail: \\ imamutama20@gmail.com
}

${ }^{* *)}$ Faculty of Law, Universitas Islam Sultan Agung (UNISSULA) Semarang, E-mail: kusriyah@unissula.ac.id

$\left.{ }^{* * *}\right)$ Faculty of Law, Universitas Islam Sultan Agung (UNISSULA) Semarang, E-mail: widhihandoko@unissula.ac.id

\begin{abstract}
A notary is a public official who is authorized to make an authentic deed as long as the making of a certain authentic deed is not reserved for other public officials. Making authentic deeds is required by laws and regulations in order to create certainty, order and legal protection. The notary's responsibility when viewed from Act No. 30 of 2004 as amended by Act No. 2 of 2014 concerning the Position of a Notary is very closely related to the duties and work of a notary. It is said so because in addition to making authentic deeds, notaries are also assigned and responsible for registering and ratifying letters/deeds made under the hand. Progressive legal knowledge possessed by a notary will also contribute to developing knowledge about notary law. The problems in this study include how the notary's responsibility in making authentic deeds for the benefit of the community is seen from the point of view of progressive law. This study uses a normative juridical research method with descriptive research specifications where this study aims to describe a comparison of legal problems that occur in certain areas or at certain times. This study uses secondary data sources which are divided into primary legal materials, secondary and tertiary legal materials. The research results that have been collected are then analyzed qualitatively.
\end{abstract}

Keywords: Notary; Responsibilities; Authentic; Deed; Progressive.

\section{Introduction}

The State of Indonesia is a State of Law as stated in Article 1 paragraph (3) of the 1945 Constitution. The state of law in question is a state that upholds the rule of 
law to uphold truth and justice and there is no power that is not accounted for. ${ }^{1}$ To ensure order and legal protection, authentic written evidence is needed regarding acts, agreements, stipulations and legal events made before or by an authorized official. ${ }^{2}$

A notary is a public official who is authorized to make an authentic deed as long as the making of a certain authentic deed is not reserved for other public officials. Making authentic deeds is required by laws and regulations in order to create certainty, order and legal protection. In addition to an authentic deed made by or before a Notary, not only because it is required by laws and regulations, but also because it is desired by interested parties to ensure the rights and obligations of the parties for the sake of certainty, order, and legal protection for interested parties at the same time. The definition of an authentic deed according to Article 1868 of the Civil Code, reads that: "An authentic deed is a deed in the form determined by law,

Law has a function to provide protection for human interests. Therefore, the law must be implemented so that human interests can be protected. In practice, the law can take place normally and peacefully, but there can also be violations of the law in practice. In this case the law that has been violated must be enforced. It is through law enforcement that the law becomes a reality. In enforcing the law there are three elements that must always be considered, namely legal certainty (Rechtssicherheit), expediency (Zweckmassigkeit) and justice (Gerechtigkeit). Laws must be implemented and enforced. Everyone hopes that the law can be enacted in the event of a concrete event. How the law must apply "fiat justitia et pereat mundus" (even though the world is collapsing the law must be enforced). That is what legal certainty wants. People expect legal certainty. Because with legal certainty, society will be more orderly. On the other hand, the community expects benefits in implementing or enforcing the law. The community is very concerned that in the implementation or enforcement of the law, justice is considered. In the implementation or enforcement of the law must be fair. The law must be adjusted to the development and dynamics of life. He does not only function to create security and public order (Kamtibnas). Furthermore, he must create better welfare for the people. People expect legal certainty. Because with legal certainty, society will be more orderly. On the other hand, the community expects benefits in implementing or enforcing the law. The community is very concerned that in the implementation or enforcement of the law, justice is considered. In the implementation or enforcement of the law must be fair. The law must be adjusted to the development and dynamics of life. He does not only

\footnotetext{
${ }^{1}$ Majelis Permusyawaratan Rakyat Republik Indonesia, 2010, Panduan Pemasyarakatan.

2 M. Luthfan Hadi Darus, Hukum Notariat Dan Tanggungjawab Jabatan Notaris, (Yogyakarta: Uii Press, 2017), p.1.
} 
function to create security and public order (Kamtibnas). Furthermore, he must create better welfare for the people. ${ }^{3}$

A notary is a public official who is authorized to make an authentic deed as long as the making of a certain authentic deed is not reserved for other public officials. Making authentic deeds is required by laws and regulations in order to create certainty, order and legal protection. In addition to the authentic deed made by or before a Notary, not only because it is required by laws and regulations, but also because it is desired by interested parties to ensure the rights and obligations of the parties for the sake of certainty. Civil society must understand the importance of a legal need or legal formation needed by the community, In practice, notaries are required to understand legal sources and legal theories that can assist in carrying out their duties and solving problems for the benefit of the community without violating the law and legal protection for interested parties as well as for society as a whole.

The term legal discovery is usually defined as the process of law formation by judges or other legal officers who are given the task of implementing the law or applying general legal regulations to concrete legal events. ${ }^{4}$ Notary is one of the legal officers who are authorized by the State in the field of civil society issues, so the Notary needs to adjust the law needed by the community in terms of solving problems that arise in social life in the form of a written agreement known as an authentic deed, for the sake of creating The sense of justice desired by the parties involved in the agreement also protects the interests of the Notary in making an authentic deed, so progressive law by the Notary profession is indispensable.

\section{Research Methods}

To examine the problems above, the type of research used in writing this thesis is normative juridical research with descriptive research specifications where this study aims to describe a comparison of legal problems that occur in certain areas or at certain times. This study uses secondary data sources which are divided into primary legal materials, secondary and tertiary legal materials. The research results that have been collected are then analyzed qualitatively.

\section{Result and Discussion}

\subsection{Position Case}

\footnotetext{
${ }^{3}$ Widhi Handoko, Dominasi Negara Terhadap Profesi Notaris Antara Ide Dan Realita, (Bogor: Roda Publika, 2019), p. 39.

4 Sudikno Mertokusumo, Penemuan Hukum Sebuah Pengantar, (Yogyakarta: Cahaya Atma Pustaka, 2014), p., 49
} 


\section{a) First Position Case}

Notary Charged Because of False Letter Coming from an Appearer, According to the Public Prosecutor, R Suharto, Notary and PPAT, having an office at Jalan Dr. Wahidin No. 26 Sidoarjo, deliberately gave the opportunity, facilities or information for falsification of letters against an authentic deed, namely in the form of information in the deed of binding sale and purchase No. 28 of 2000 dated November 13, 2000 and deed of power of attorney No. 26 of Sidoarjo. 29 November 13, 2000.

YAPI KUSUMA came before the Notary with a power of attorney under hand dated September 1, 1999 from VENTJE REIN CAROLES (President Director of PT. Bintang Karyasama) to witness YAPI KUSUMA (as Head of Division of PT. Bintang Karyasama), the contents of which are as if VENTJE REIN CAROLES authorized YAPI KUSUMA to represent PT. Bintang Karyasama, conducted land and building sale and purchase transactions with KURNIAWATI.

It turned out that the personal power of attorney which was used as the basis for making the notarial deed was fake, therefore the Public Prosecutor charged the Notary with articles of forgery of authentic deeds/letters and inclusions, Primary charges: Article 264 paragraph (1) in conjunction with Article 56 number 2 of the Criminal Code, Subsidiary indictment: Article 263 paragraph (2) in conjunction with Article 56 paragraph 2 of the Criminal Code ${ }^{5}$.

In this case, the Panel of Judges of the District Court decided by declaring that the Defendant R. SOEHARTO, SH mentioned above was not legally and convincingly proven to have committed the criminal act that was charged to him in the Primary indictment; acquit him therefore of the primar charge ; and Stating that the act that was indicted against the Defendant: R. SOEHARTO, SH in the Subsidiary's indictment has been proven, but the act is not a criminal act; Release the Defendant : R. SOEHARTO, SH from all lawsuits.

Not accepting the decision, the Public Prosecutor also made an appeal. However, the Supreme Court through Supreme Court Decision No. No. 385 K/Pid/2006 actually benefits Notary R. SOEHARTO, namely: To declare that the Defendant: R. SOEHARTO, SH above has not been legally and convincingly proven guilty of committing the crime charged in the Primary and Subsidiary charges; Freed him therefore from the Primary and Subsidiary charges.

\section{b) Second Position Case}

\footnotetext{
${ }^{5}$ A Chuasanga, Ong Argo Victoria. (2019). Legal Principles Under Criminal Law in Indonesia Dan Thailand, Jurnal Daulat Hukum, Vol 2, No 1 (2019) http://jurnal.unissula.ac.id/index.php/RH/article/view/4218
} 
This case occurred in Pekanbaru, Riau Province, which involved a notary in falsifying an authentic deed. In the follow-up trial of the alleged crime of document forgery with the defendant Neni Sanitra SH as a Notary, Edward Purba as a witness admitted that there were a number of items (contents) of agreements (documents) that were deleted and changed by Neni.

This confession was conveyed by Edward at a follow-up hearing held at the Pekanbaru District Court (PN), on Thursday (27/11/14). He was presented as a witness by the Public Prosecutor (JPU) from the Pekanbaru District Attorney (Kejari) Minda and Wilsa. "I once went to the defendant's office (Neni). There, I saw that there were several items in the agreement deed that were deleted and thickened," said Edward.

However, when asked who asked Neni to change the contents of the agreement, before the Panel of Judges chaired by Sutarto, Edward admitted that he did not know. Because, with the alleged fake deed, PT BI felt aggrieved and the other party benefited.

\subsection{Legal Certainty Theory, Legal Expediency, Liability, Progressive Law}

Legal certainty as one of the objectives of the law can be said as part of efforts to realize justice. The real form of legal certainty is the implementation or enforcement of an action regardless of who does it. With legal certainty, everyone can predict what will be experienced if they take certain legal actions. Certainty is needed to realize the principle of equality before the law without discrimination. ${ }^{6}$

Utilitarianism has the view that the purpose of law is to benefit as many people as possible. Benefit here is defined as happiness, so that the assessment of whether a law is good or bad or not depends on whether the law gives happiness to humans or not. Thus, it means that every preparation of legal products (laws and regulations) should always pay attention to the purpose of the law, namely to provide as much happiness as possible for the community.

Applied Theory (Application Theory), in this case the theory used is the Theory of Responsibility. According to Hans Kelsen, his theory of legal responsibility states that: ${ }^{7}$ "A person is legally responsible for a certain act or that he bears legal responsibility, the subject means that he is responsible for a sanction in the case of a contrary act".

\footnotetext{
${ }^{6}$ Bodenheimer dalam Satjipto Rahardjo, Ilmu Hukum, (Bandung: PT. Citra Aditya Bakti, 2006), p. 277.

${ }^{7}$ Somardi. 2007. General Theory of Law and State, Teori Umum Hukum dan Negara, Dasar-Dasar IImu Hukum Normatif Sebagai Ilmu Hukum Deskriptif Empirik. Jakarta: BEE Media Indonesia, p. 81.
} 
Progressive law views that the law is for humans. So the law is to make people happy, the law is to serve human interests. Not a man for the law. Prof. Satjipto especially in the final years of his life alluded to what is called deep ecology. This concept implies that the law is no longer solely for humans, but to make all living beings happy. "It means law for all living things".

Based on the two position cases that the author conveys in this study, it will be possible to see a comparison of the actions or actions taken by the notary involved in the two position cases, so that later the reader can find out whether the notary's actions can be accounted for or who can be responsible for the mistakes in the authentic deed. Every mistake in the authentic deed the absolute responsibility of the notary as a public official who is authorized to make an authentic deed regarding all acts of agreement and engagement, or can it be accounted for by other parties based on certain actions or actions outside of the notary's responsibility as regulated in Indonesian positive law.

According to the author's observations, there are several factors that must be considered whether the actions of a Notary can be judged as $\mathrm{PMH}$ (Unlawful Actions) which will be described as follows:

\section{1) Notary Authority in Making Authentic Deed}

From the research that the author has conducted, the author can conclude that if one of the requirements for authority is not met, the deed made by or before a notary does not have the status as an authentic deed and only has the power of proof such as an underhand deed if the deed is signed by the parties. Notaries in carrying out their duties in addition to being given authority, are also required to comply with the obligations regulated by UUJN and the Notary Code of Ethics and are required to avoid prohibitions in carrying out their positions as public officials.

2)

Obligations of a Notary in Making an

Authentic Deed

Based on the explanation of Article 16 UUJN above that a Notary in carrying out his duties as a public official, a Notary not only has the authority but also has several obligations that must be obeyed as stipulated in the UUJN. So that in carrying out their duties, the Notary must be guided by the UUJN in order to remain aware of what is the obligation of the Notary Profession in carrying out their duties. That if it is understood again the regulation of the obligations of the Notary Profession which has been regulated in the UUJN is actually a form of adding to the duties and authorities of a Notary so that there is uniformity in carrying out his duties and authorities as a public official according to the provisions of the law.

3) Prohibition for Notaries 
Based on the explanation described above, that a Notary in carrying out his duties and authority as a public official is not given extra power but also has some limitations that become the control for the Notary profession so that it does not get out of what is actually the duty and authority in accordance with the provisions that have been made regulated in legislation, positive law, as well as norms that exist and live in Indonesian society.

\section{4) Notary Responsibilities}

Based on the research that the author has done that the Notary as a Public Officia has responsibility for the deed he made, the Notary's Responsibility according to article 65 of the UUJN can be understood that the responsibility for the deed that has been made by the Notary is attached until the Notary dies. Some of the responsibilities that exist in the Notary can be in the form of Criminal Liability, Civil Liability, Administrative Responsibilities.

\subsection{Use of Legal Certainty Theory, Legal Expediency, Liability, Progressive Law}

From the points that the author has conveyed above, it can be seen how the description of the unlawful act that Notary Neni Sanitra did, the act is inversely proportional to the case of the first position, in carrying out his duties, Notary Neni Sanitra should be able to uphold the oath of appointment of a Notary, understand the values Norm values that exist in society are also based on existing laws and regulations so that they do not get out of their authority in carrying out their duties.

That from the case of the first position and the case of the second position put forward by the author, it can be seen that the comparison of the actions carried out by the two notaries. The notary in the first position case makes an authentic deed on the basis of document falsification in the form of a power of attorney carried out by the appearer without the knowledge of the notary so that the act cannot be held accountable to the notary. In the case of the second position, the act committed is an act against the law where the criminal element contained in Article 263 paragraph 1 of the Criminal Code: "Anyone who makes a fake letter or falsifies a letter that can give rise to a right, engagement or debt release, ${ }^{8}$ Based on the juridical explanation contained in the regulation, we can see the linkage of the criminal element which the author can believe has fulfilled all the elements that can bring the notary to the judicial process.

The conclusion that we can draw from the actions contained in the case of the first position and the case of the second position is that in carrying out his duties and authorities a Notary should understand the norms that exist in society, also

${ }^{8}$ Article 263 Paragraph 1 of the Criminal Code 
always be guided by the legislation and existing positive laws so that can carry out their duties in accordance with existing regulations.

In carrying out their duties, the Notary must also understand the existing legal theory in the form of the Theory of Justice, Certainty, Benefit, and Progressive Law. This understanding can help Notaries in every decision making or in solving legal problems that exist in the community, so that Notaries are not rigid and active in providing legal services or legal services to the community ${ }^{9}$.

Based on the results of the research that the author did, the writer hereby will describe some of the responsibilities that can be imposed on the Notary, as well as what deed can be progressed by the Notary as follows:

\section{a. Civil Liability}

Civil sanctions are sanctions imposed on errors that occur as a result of default or acts that violate the law onrechtmatige daad. Civil sanctions can be in the form of reimbursement of costs, compensation and interest. The notary will be asked for sanctions if he gets a lawsuit from the appearers who feel aggrieved because the deed in question is legally flawed, so that it has the power of proof as an underhand deed or null and void.

Compensation of costs, compensation and interest can be sued to a notary based on the notary's legal relationship with the parties facing the notary, so that the notary can be held civilly responsible for the deed he made. The claim for reimbursement of costs, compensation and interest against a notary is not based on the position of the evidence that has changed due to violating certain provisions in the UUJN, but is based on the legal relationship that occurs between the notary and the parties who appear before the notary. Even though the notary has retired. The notary must still be responsible civilly for the deed he has made ${ }^{10}$.

\section{b. Criminal Liability}

In practice, it is often found that if there is a notarial deed disputed by the parties or other parties, the notary is often withdrawn as a party who participates in committing or assisting in committing a crime, namely providing false information in the notary deed. With this, it creates confusion as to whether it is possible that the notary intentionally erred or made a mistake together with the parties to make

${ }^{9}$ Deen, Thaufiq., Ong Argo Victoria \& Sumain. (2018). Public Notary Services In Malaysia. JURNAL AKTA: Vol. 5, No. 4, 1017-1026. Retrieved from http://jurnal.unissula.ac.id/index.php/akta/article/view/4135

10 Ong Argo Victoria, (2018) Waqf Al-Nuqūd In Indonesia (In Law Perspective), Jurnal Pembaharuan Hukum Vol 5, No 1 Universitas Sultan Agung, http://jurnal.unissula.ac.id/index.php/PH/article/view/2999 
a deed intended to commit a criminal act. If the notary is proven to have violated this, it is obligatory for him to be given sanctions.

In connection with the above, in order to request a notary statement on the report of a certain party according to Article 66 of the UUJN Number 2 of 2014, if a notary is summoned by the Police, the Prosecutor's Office, or a Judge, the agency wishing to summon must seek approval from the Notary Honorary Council. The provisions of article 66 of the UUJN This is imperative for the Police, Prosecutors, or Judges, which means that if the Police, Prosecutors, and Judges underestimate the provisions of Article 66 of the UUJN, it can be categorized as a violation of the law. When a person is not allowed to be summoned, the Police or the Prosecutor's Office will summon witnesses from the notarial deed mentioned at the end of the deed. This is actually not in accordance with applicable notarial law.

The imposition of criminal sanctions against notaries can be carried out as long as these limits are violated, which means that in addition to fulfilling the formulation of the violation in the UUJN, it must also fulfill the formulation in the Criminal Code. Examination of the notary must be able to prove the mistakes made by the notary intellectually, in this case the power of legal logic is very much needed in the notary examination process. ${ }^{11}$

Violation of Article 266 paragraph (1) of the Criminal Code can only be suspected of a Notary when he knows that the information requested by the parties to be included in the deed is not true but the Notary is still willing to make the deed, then the Notary in this case can be charged with committing a crime Article 266 paragraph (1) KUHP Jo. Article 56 paragraph (1) of the Criminal Code, with the maximum penalty that can be imposed for acts of assisting a crime Article 266 paragraph (1) of the Criminal Code.

\section{c. Administrative Responsibilities}

In addition to the civil and criminal sanctions imposed, administration. Administrative sanctions for notaries as regulated in UUJN have been determined as follows:

1) verbal warning;

2) written warning;

3) temporary suspension;

4) honorable discharge;

${ }^{11}$ Results of an interview with H. Mufti Nokhman., Bengkulu City Notary 
5) dishonorable dismissal and against a notary if he commits a violation, there are also sanctions.

Sanctions against a notary in the form of temporary dismissal from his position are intended so that the notary does not carry out his duties for a while before the sanction in the form of honorary discharge or dishonorable discharge is imposed on the notary. The imposition of this sanction can end in the form of restitution to the notary to carry out his duties again or be followed up with a sanction of honorable discharge or dishonorable discharge. To provide certainty, the time limit for the temporary dismissal must be determined, so that the fate of the notary is not suspended. This temporary dismissal sanction is a real coercion, while the sanction of honorary dismissal or dishonorable dismissal is included in the realm of sanctions for dissolving favorable decisions.

\section{Closing}

Based on the discussion carried out, the following conclusions are obtained: 1 ). Notary Authentic Deed Proof as evidence is the perfect power of proof, because the specialty of an authentic deed lies in the strength of its proof. An authentic deed provides the parties and their heirs or the people who have rights from it a perfect proof. An authentic deed has the power of proof in such a way which is considered attached to the deed itself, meaning that the authentic deed is a binding evidence because what is written in the deed must be considered true and guaranteed protection by the state through existing laws and regulations. 2) Legal responsibility by the Notary in making the Authentic Deed is closely related to the obligations and sanctions given to the Notary. Notaries are authorized to make authentic deeds as stipulated in Article 15 of the UUJN. Notaries in carrying out their authority have obligations that must be carried out as stipulated in Article 16 of the UUJN. Article 16 UUJN also regulates the provisions of sanctions for Notaries who do not carry out their obligations. A Notary in making an Authentic Deed must comply with the provisions as stated in Chapter VII UUJN concerning Authentic Deeds. Violation or non-fulfillment of the provisions in the articles regarding the authentic deed result in sanctions for the Notary and the Notary's responsibilities in civil law. Obligations and sanctions are legal responsibilities given to a Notary. 3) Notaries in carrying out their duties and authorities as public officials who are given the authority to make a legal product in the form of an Authentic Deed always serve the interests of the community in order to achieve legal goals in the form of Justice, Benefit, and Legal Certainty. A Notary is also required to always be solvative in dealing with private legal problems faced by the community, so that the need for knowledge of progressive legal theory by a Notary as a basis for thinking in dealing with existing legal problems. Progressive legal knowledge possessed by a notary will also contribute to developing knowledge about notary law. 


\section{References}

Al-Quran and Hadith

Journals:

[1] A Chuasanga, Ong Argo Victoria. (2019). Legal Principles Under Criminal Law in Indonesia Dan Thailand, Jurnal Daulat Hukum, Vol 2, No 1 (2019) http://jurnal.unissula.ac.id/index.php/RH/article/view/4218

[2] Deen, Thaufiq., Ong Argo Victoria \& Sumain. (2018). Public Notary Services In Malaysia. JURNAL AKTA: Vol. 5, No. 4, 1017-1026. Retrieved from http://jurnal.unissula.ac.id/index.php/akta/article/view/4135

[3] Ong Argo Victoria, (2018) Waqf Al-Nuqūd In Indonesia (In Law Perspective), Jurnal Pembaharuan Hukum Vol 5, No 1 Universitas Sultan Agung, http://jurnal.unissula.ac.id/index.php/PH/article/view/2999

Books:

[1] Bodenheimer dalam Satjipto Rahardjo, IImu Hukum, (Bandung: PT. Citra Aditya Bakti, 2006)

[2] M. Luthfan Hadi Darus, Hukum Notariat Dan Tanggungjawab Jabatan Notaris, (Yogyakarta: Uii Press, 2017)

[3] Majelis Permusyawaratan Rakyat Republik Indonesia, Panduan Pemasyarakatan, 2010

[4] Somardi, General Theory of Law and State, Teori Umum Hukum dan Negara, Dasar-Dasar IImu Hukum Normatif Sebagai IImu Hukum Deskriptif Empirik. (Jakarta: BEE Media Indonesia, 2007)

[5] Sudikno Mertokusumo, Penemuan Hukum Sebuah Penganta, (Yogyakarta: Cahaya Atma Pustaka, 2014)

[6] Widhi Handoko, Dominasi Negara Terhadap Profesi Notaris Antara Ide Dan Realita, (Bogor: Roda Publika, 2019)

Regulations:

[1] Act No. 2 of 2014 concerning Amendments to Act No. 30 of 2004 concerning the Position of Notary

[2] Code of Civil law

[3] Constitution 1945

Internet:

[1] Beritariau.com, Parah! Notaris Senior Neni Sanitra ternyata palsukan akta perjanjian, https://www.beritariau.com/berita-1228-parah-notarissenior-neni-sanitra-ternyata-palsukan-akta-perjanjian.html 
[2] Zul Fadli, Notaris Didakwa Gara-Gara Surat Palsu yang Berasal dari Penghadap, $\quad$ https://haloindonesianews.com/2021/06/23/notarisdidakwa-gara-gara-surat-palsu-yang-berasal-dari-penghadap/

Interview:

Results of an interview with H. Mufti Nokhman., Bengkulu City Notary 